\title{
Growth performance of broiler chickens fed maize offal and crayfish-waste based
} diets

Nsa, E. E. and Essien, A. I.

Department of Animal Science, University of Calabar,

Calabar, Cross River, Nigeria.

Corresponding author: essienkate@gmail.com; 07033432868

\section{Abstract}

This study was conducted to evaluate the value of maize offal and cray fish waste meals as the main energy and protein sources respectivelys in broiler chicken diets. One hundred and twenty day-old-Lohmann Brown broiler chicks were randomly allotted into two treatment groups of three replicates of 60 and 20 birds, respectively. Maize offal and crayfish waste meals were used to replace maize and soybean/fishmeal, respectively in the control diet $\left(T_{1}\right)$ to form $\left(T_{2}\right)$. Growth parameters monitored were final live weight, daily weight gain, feed conversion ratio, internal and external body linear measurements were evaluated were statistically analysed using the studentized t-test at 5\% and 1\% probability. Results showed significantly $(P<0.05)$ higher values in all the parameters apart from feed intake for birds on the control diet. The final live weight of birds on the test diet $\left(T_{2}\right)$ only reached that of the control at 10 weeks of age. The phenotypic correlation of body weight and linear body measurements for birds on both the control and test treatment diets were high and positively significant $(P<0.01)$. However, birds on the control diet had the longest body parts than those of the test diet, likewise the internal body parts. When expressed based on percentage body weight, birds on the test diet tended to have longer external and internal body parts. It is concluded that if maize offal and crayfish waste are to be used as total replacement for maize, soybean and fishmeal, the period of broiler production should be extended from 8 weeks to 10 weeks for birds to reach market weight and with attendance lower cost of production.

Keywords: Maize offal, crayfish waste, phenotypic correlation, linear measurement

\section{Introduction}

Feed is the major component of the total cost of livestock production, representing $70-75 \%$ of the total cost of production (Esonu et al. 2008). A way of reducing this trend is for producers to direct their efforts towards harnessing and utilizing unorthodox feed ingredients like agro industrial by products in order to save man and his livestock from starvation (Ojabo et al., 2014). Agroindustrial by-products can be derived from the product from stages of food processing or industrial processing of a target product. Two of such are crayfish waste and maize offal. Crayfish waste is derived from commercial crayfish and other marine organisms from the sea and rivers. They are usually dried and sieved, the waste discarded is the crayfish waste which could be used as a protein supplement or replacement in livestock and poultry feeds. Crayfish wastes is made up of shrimps, shrimp's heads, shell, tendrils, sea debris and so on. The crude protein varies from $30-70 \%$ based on the amount of the above components (Olomu, 2010). However, most of the protein comes from the chitin, an indigestible nitrogen containing polysaccharide, but is high in choline and contains some important carotenoids (Fanimo et al.,2007; Olomu, 2010 Ukoha et al., 2019). In recent times, the waste is being sold as a result of high demand by farmers who realize its usefulness in livestock and poultry feeds. Maize residue (offal) is an energy source by - product derived from maize after the extraction of starch "Ogi". Although, it has 


\section{Growth performance of broiler chickens fed maize offal and crayfish-waste based diets}

low energy but high protein level when compared to maize. Nsa et al. (2009) andOgungbeuro et al. (2013) reported a high fibre content of $11.36 \%$ and crude protein content of $11.05 \%$ for maize offal. Its usage in poultry diet especially for young birds is limited by its fibre content especially when other fibre sources like wheat offal and palm kernel cake are included (Hedge et al., 1978). Thus, the objective of this study was to assess the growth performance phenotypic correlation for body weight and linear body measurements of broiler chickens fed diets with maize offal and crayfish waste as the only energy and protein sources.

\section{Materials and methods Experimental site}

The experiment was carried out at a standard Poultry Unit located at the Federal Housing Estate, Calabar, Nigeria. Calabar is located within the tropical rain forest zone of Nigeria. It lies between latitude $4^{0} 58^{1} \mathrm{~N}$ and $41^{0} 39^{\prime} \mathrm{N}$ and longitude $8^{0} 17^{1} \mathrm{E}$ and $10^{\circ} 43^{\prime} \mathrm{E}$ of the equator with annual temperate and rainfall ranges between 25$30^{\circ} \mathrm{C}$ and $1260-3500 \mathrm{~mm}$ respectively (Google Earth, 2017).

\section{Experimental diets}

Maize offal was purchased from local "Ogi" sellers within Calabar Municipality. They were sundried by spreading on concrete slab and allowed to dry for 23 days to a constant moisture level of $10 \%$ before being stored in jute bags.

Crayfish waste was bought from crayfish sellers in Calabar South Local Government Area and thereafter dried and milled with a meadow model 35 hammer mill and stored in sack bags. Representative samples of both test ingredients were analysed for proximate composition. Maize offal and crayfish waste were made to replace the energy source (maize) and protein sources (soybean and fish meal) respectively in the control diet $\left(\mathrm{T}_{1}\right)$ to form treatment $\operatorname{diet} \mathrm{T}_{2}$ (Table 1).

\section{Experimental animals and management}

One hundred and twenty Lohmann Brown broiler chicks were purchased from a reputable farm. They were weighed and randomly allotted to two treatment groups and within each treatment groups, birds were divided into three replicates of 20 birds each. Each bird was marked for easy identification and housed in a deep litter pen. All routine vaccination and medications were given. Birds were offered experimental starter diet for the first four weeks followed by experimental finisher diets for the next four weeks. Parameters measured included: Records of daily feed intake and weekly weight gain were taken throughout the eight weeks of the experiment. At the end of $8^{\text {th }}$ week, the birds were starved overnight, weighed, slaughtered, de-feathered, eviscerated and cut into primal parts for external and internal parts measurement with the use of a sensitive weighing balance of $0.05 \mathrm{~g}$ sensitivity and a measuring tape calibrated in centimetres.

\section{Statistical analysis}

The studentized t-test was used to analyzed and compare between two means. Regression model: Traits studied were body weight, body circumference, body length, body height, shark length, leg length, thigh length, head circumference, wing length and knee angle using simple linear regression analysis (SAS, 2012). 
Nsa and Essien

Table 1 : Composition of experimental starter and finisher diets of broile $r$ chickens fed maize offal crayfish waste based diet

\begin{tabular}{|c|c|c|c|c|c|c|}
\hline \multirow{2}{*}{$\begin{array}{l}\text { Diets } \\
\text { Ingredients }\end{array}$} & \multicolumn{2}{|l|}{ Starter diets } & \multicolumn{2}{|c|}{ Finisher diets } & \multirow[b]{2}{*}{ Maize offal } & \multirow[b]{2}{*}{$\begin{array}{l}\text { Cray fish } \\
\text { waste }\end{array}$} \\
\hline & $T_{1}$ (control) & $\mathbf{T}_{2}$ & $T_{1}$ (control) & $\mathbf{T}_{2}$ & & \\
\hline Maize & 54.50 & - & 60.00 & - & & \\
\hline Maize offal & - & 71.00 & - & 73.50 & & \\
\hline Soybean meal & 32.00 & - & 25.00 & - & & \\
\hline Wheat offal & 7.10 & - & 8.60 & - & & \\
\hline Fish meal & 2.50 & - & 2.50 & - & & \\
\hline Crayfish waste & - & 24.50 & - & 18.50 & & \\
\hline Palm oil & - & 2.00 & - & 5.5 & & \\
\hline Bone meal & 3.00 & 2.00 & 3.00 & 2.00 & & \\
\hline Salt & 0.30 & 0.30 & 0.30 & 0.30 & & \\
\hline Lysine & 0.20 & - & 0.20 & - & & \\
\hline Methionine & 0.20 & - & 0.20 & - & & \\
\hline *Vit/min premix & 0.20 & 0.20 & 0.20 & 0.20 & & \\
\hline Total & 100.00 & 100.00 & 100.00 & 100.00 & & \\
\hline \multicolumn{7}{|c|}{ Calculated analysis } \\
\hline $\begin{array}{l}\text { Crude protein } \\
(\%)\end{array}$ & 23.00 & 23.51 & 20.0 & 21.03 & 11.38 & 58.90 \\
\hline Crude fibre $(\%)$ & 3.85 & 6.71 & 4.26 & 7.88 & & \\
\hline ME(Kcal/Kg) & 2885.50 & 2508.92 & 3001.83 & 2544.00 & & \\
\hline \multicolumn{7}{|c|}{ Determined analysis } \\
\hline Crude fibre \% & & & & & 8.82 & 2.01 \\
\hline Ether extract \% & & & & & 3.04 & 3.67 \\
\hline
\end{tabular}

*Composition per 2kgof mixture contains; Vitamin A - 15,000,000 iu, Vitamin D - 3,000,000 iu, Vitamin E - 15,000 iu, Vitamin K - 2.5g,

Vitamin $B_{1}-1 \mathrm{~g}$, Vitamin $B_{2^{-}}$10g, Vitamin $B_{12^{-}}$gg, Folic acid - 2g, Biotin - 0.1g, Niacin - 70g, BHT - 125g, Calcium-Pantotenic acid - 20g

\section{Model Function}

Linear $\mathrm{Y}=\mathrm{a}+\mathrm{bx}$

Where

$\mathrm{Y}=$ body weight (dependent variable)

$\mathrm{N}=$ body parameters (independent

variables)

$\mathrm{b}=$ slope

$\mathrm{a}=\mathrm{y}-\mathrm{bx}$

Where $\mathrm{y}$ and $\mathrm{x}=$ means of $\mathrm{y}$ and $\mathrm{x}$ respectively

\section{Cost analysis}

The following formulae were used to determine the economics of production of the birds.

Cost of weight gain $=$

Average wt gain kg) X cost of feed (N)

Weight gain $(\mathrm{kg})$

Cost of feed $/ \mathrm{kg}$ weight gain $=$

cost of feed (N/kg) X Ave feed consumed $(\mathrm{Kg})$

Average weight gain $(\mathrm{kg})$

Relative cost benefit $(\%)=$ cost of feed
$(\mathrm{N} / \mathrm{kg})$ weight gain of control diet - cost of feed $(\mathrm{N} / \mathrm{kg})$ weight of test diet $\mathrm{x} 100 /$ cost of feed $(\mathrm{N} / \mathrm{kg})$ weight gain of control diet

Cost differential $=$ cost of feed $/ \mathrm{kg}$ weight

\section{Results and discussion}

The result of growth performance of broiler chickens fed diet with maize offal and crayfish waste as the main sources of energy and protein is presented in Table 2. Apart from feed intake, birds on the control diet $\left(\mathrm{T}_{1}\right)$ had significantly $(\mathrm{P}<0.05)$ favourable growth parameters. The higher $(\mathrm{P}<0.05)$ feed intake observed from birds on the test diet $\left(\mathrm{T}_{2}\right)$ could be attributed low energy and high fibre of the diet, which is in the consonance with the reports of Olumu (2010), Oyawoye et al. (2012), Nsa et al. (2013that birds eat more to meet their requirement for some dietary components other their energy. The low energy content 


\section{Growth performance of broiler chickens fed maize offal and crayfish-waste based diets}

of maize offal which contributed to the low energy content of the feed according to Reddy (2007) could be the cause of high feed intake since birds eat to meet their energy requirement. The more favourable values were recorded in birds fed the control diet in all other growth parameters; final live weight, weight gain and feed conversion ratio indicated that maize offal and crayfish waste diet lack necessary nutrients to support birds' optimum performance. The fibre content in starter and finisher mashes were above the recommended values by NRC (2000) of $4 \%$ and $5 \%$ for starter and finisher birds. These levels can hamper growth performance as it acts as a diluent and as a barrier to the attack of intracellular compounds by enzymes of the gastro intestinal tract (Tashrio and Maki, 1979). High fibre in feed increases the transit rate resulting in decrease nutrient absorption which according to Knogdah (1986) reduces the protein and energy utilization to about $20 \%$ under practical condition.

The results of external and internal body parts are presented in Table 4. Birds on the control diet $\left(\mathrm{T}_{1}\right)$ had significantly $(\mathrm{P}<0.05)$ higher values for external body parts than birds on the test $\operatorname{diet}\left(\mathrm{T}_{2}\right)$. This was expected since body weight of bird is directly correlated with body parts (Ezzeldin et al., 1994). However, when expressed based on percentage live weight the values for birds on test diet seem to be significantly $(\mathrm{P}<0.05)$ higher than that of birds on control diet. This observation could be attributed to the fact that the birds on test diet thou small in size but were of the age and the organs were relatively developed but not directly proportional to the body live weight. The internal body parts values showed the same pattern as external body parts in terms of higher values for birds on the control diet $\left(T_{1}\right)$ than birds on the test diet $\left(T_{2}\right)$. An indication that body live weight is directly proportional to the internal organ development. When expressed based on percentage body the reverse was the case where the internal body weights were higher than that of birds on the control diet. The same explanation as that of the external body parameters could be given as all birds were of the same age with relatively mature organs for effective metabolic functions. The equation estimate of parameter and coefficient of determination of the fitted functions are presented in Table 4 which demonstrated a strong inter-relationship $(\mathrm{P}<0.001)$ between body weight and linear body measurements. The prediction equation showed that body weight in broiler chicken fed both the control diet and test diet is linearly related to the body measurements especially the thigh length, body length and shank length. The prediction equation as provided in this study using high length, body length and shank length can assist producers and buyers to have accurate and easy means of estimating body weight of broiler chickens on both diets without resorting to weighting the birds. Coefficient of determination $\left(\mathrm{r}^{2}\right)$ varied from $83 \%$ to $97 \%$ for head circumference and thigh length in birds on control diet $\left(\mathrm{T}_{1}\right)$ while for birds or test diet $\left(\mathrm{T}_{2}\right)$, coefficient of determination $\left(\mathrm{r}^{2}\right)$ varied from $94 \%$ to $99 \%$ for body length and thigh length. These results showed high accuracy of prediction of body weight, which is in line with the reports of Adeniyi and Ayorinde (1990), Monsis (1992), Adeleke et al. (2004) and Peter et al. (2006) who reported that shank length, thigh length and body length could be used effectively to predict body weight of chicken. 
Nsa and Essien

Table 2: Performance of experimental birds fed maize offal- crayfish waste based diet

\begin{tabular}{|c|c|c|c|}
\hline Parameters & $T_{1}$ control & $\mathbf{T}_{2}$ & LOS \\
\hline Initial body weight(g) & 71.74 & 73.72 & NS \\
\hline Daily feed intake (g) & 69.86 & 85.66 & $\mathrm{~S}$ \\
\hline Total feed intake at 8 weeks & 4172.62 & 5621.50 & $\mathrm{~S}$ \\
\hline Total feed intake at 10 weeks & - & 6890.19 & NE \\
\hline Final live weight at 8 weeks & 1208.96 & 893.41 & $\mathrm{~S}$ \\
\hline Final live weight at $10 \mathrm{wks}$ & - & 1212.60 & NE \\
\hline Daily weight gain at 8 weeks(g) & 23.21 & 16.73 & $\mathrm{~S}$ \\
\hline Daily weight gain at 10 weeks & - & 23.07 & NE \\
\hline Total weight gain at 8 weeks & 1299.79 & 936.88 & $\mathrm{~S}$ \\
\hline Total weight gain at 10 weeks & - & 1171.10 & NE \\
\hline Feed conversion ratio & 3.01 & 5.12 & $\mathrm{~S}$ \\
\hline Feed cost $/ \mathrm{Kg}(\mathbb{N})$ & 120.25 & 65.00 & S \\
\hline Total cost of feed(N) at $8 \mathrm{wks}$ & 501.76 & 365.40 & S \\
\hline Total cost of feed(N) at $10 \mathrm{wks}$ & - & 447.86 & $\mathrm{NE}$ \\
\hline Cost of feed/kg live wt gain ( at 8 wks & 385.97 & 390.01 & $\mathrm{~S}$ \\
\hline Cost of feed $/ 1 \mathrm{~kg}$ live wt gain $(\mathrm{N})$ at $10 \mathrm{wks}$ & - & 382.46 & \\
\hline
\end{tabular}

LOS $=$ level of significant, $\mathrm{S}=$ significant at $5 \%$ level, $\mathrm{NS}=$ non-Significant at $5 \%$ level, $\mathrm{NE}=$ non- estimated

Table 3: External and internal parameters of experimental birds fed maize offal -crayfish waste based diets

\begin{tabular}{lcll}
\hline Treatments & \multicolumn{1}{c}{$\mathrm{T}_{1}$} & $\mathrm{~T}_{2}$ & Los \\
\hline & External body parameters $(\mathbf{c m})$ & \\
final live weight $(\mathrm{g})$ & 1208.96 & 893.41 & $\mathrm{~S}(\mathrm{~S})$ \\
Body circumference & $24.51(2.03)$ & $22.64(2.53)$ & $\mathrm{S}(\mathrm{S})$ \\
Body length & $23.02(1.90)$ & $21.77(2.44)$ & $\mathrm{S}(\mathrm{S})$ \\
Body height & $15.06((1.25)$ & $14.42(1.61)$ & $\mathrm{S}(\mathrm{S})$ \\
Shank length & $5.10(0.42)$ & $4.34(0.48)$ & $\mathrm{S}(\mathrm{S})$ \\
Leg length & $7.39(0.61)$ & $6.82(0.76)$ & $\mathrm{S}(\mathrm{S})$ \\
Thigh length & $5.96(0.49)$ & $5.81(0.65)$ & $\mathrm{S}(\mathrm{S})$ \\
Head circumference & $9.53(0.79)$ & $8.87(0.99)$ & $\mathrm{S}(\mathrm{S})$ \\
Wing length & $13.27(1.10)$ & $13.14(1.45)$ & $\mathrm{S}(\mathrm{N})$ \\
Knee Angle & $5.22(0.43)$ & $4.70(0.53)$ & $\mathrm{S}(\mathrm{S})$ \\
& Internal body parameters (cm) & \\
Gullet & $11.24(0.93)$ & $9.54(1.07)$ & $\mathrm{S}(\mathrm{S})$ \\
Liver & $6.36(0.53)$ & $5.96(0.67)$ & $\mathrm{S}(\mathrm{S})$ \\
Gizzard circumference & $13.20(1.09)$ & $11.68(1.31)$ & $\mathrm{S}(\mathrm{S})$ \\
Small intestine & $162.38(13.43)$ & $156.82(17.55)$ & $\mathrm{S}(\mathrm{S})$ \\
Large intestine & $11.34(0.94)$ & $10.02(1.12)$ & $\mathrm{S}(\mathrm{S})$ \\
Heart circumference & $5.54(0.46)$ & $5.48(0.61)$ & $\mathrm{S}(\mathrm{N})$ \\
Lung circumference & $5.26(0.44)$ & $5.00(0.56)$ & $\mathrm{S}(\mathrm{N})$ \\
Ceca & $18.98(1.57)$ & $17.86(2.00)$ & $\mathrm{S}(\mathrm{S})$ \\
Crop & $10.20(0.84)$ & $9.58(1.07)$ & $\mathrm{S}(\mathrm{S})$ \\
Proventriculus & $4.42(0.37)$ & $4.12(0.46)$ & $\mathrm{S}(\mathrm{S})$ \\
\hline Values in brackets are expressed in percentage of live weight $(\%$ LW) S=significant at 5\% probability, N=non-significant
\end{tabular}


Growth performance of broiler chickens fed maize offal and crayfish-waste based diets

Table 4: Prediction equation for body parameters using body weight as independent variable (simple linear function)

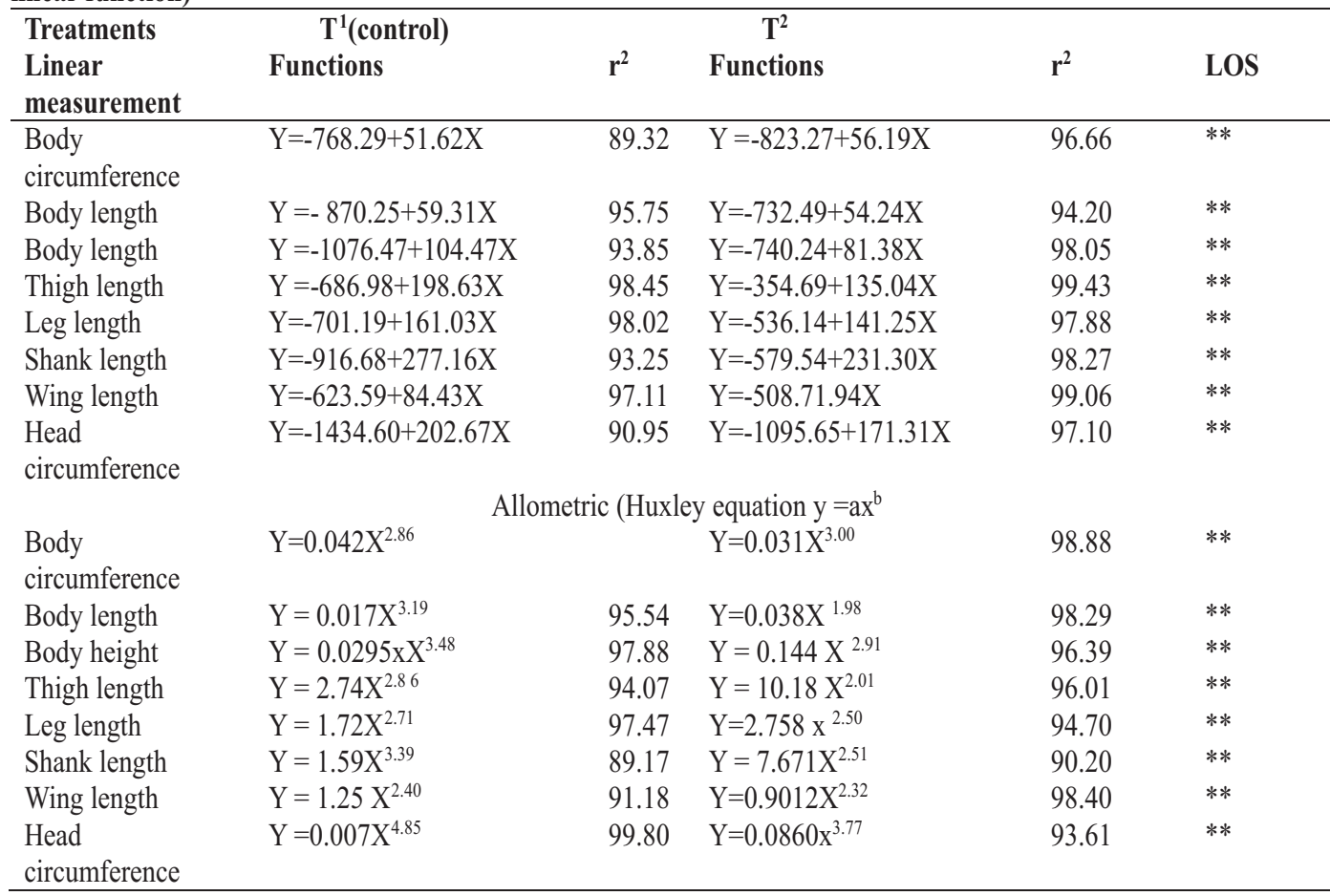

LOS= level of significant, ${ }^{* *}=$ significant at $1 \%$ probability

\section{Conclusion}

The study showed that in maize offal and crayfish waste based- diets for broiler chickens, extra two weeks should be added for birds to reach market weight.

\section{References}

Adeniji, F. O. and Ayorinde, K. I. 1990. Prediction of body weight of broilers at different ages $\mathrm{f} \quad \mathrm{r}$ o $\mathrm{m}$ some linear $\mathrm{b} \quad \mathrm{o} \quad \mathrm{d} \quad \mathrm{y}$ measurements. Nigerian Journal of Animal Production, 17:42-47.

Ezzeldin, Z. A., Hanafi, M. S., Ichal, M. M. and Sabra, Z. A. 1994. Phenotypic correlation between body weight and body measurement of chicken. Animal Breeding. Abstract. 62:475-475.

Esonu, B. O., Emenelom, O. O., Maduwere, C. C., Udedibie, A. B.
I. and Uchegbu, M. C. 2008. Evaluation of oil palm (Elgesis guinensis) leaf meal as feed ingredient in broiler diets. Nigerian Journal of Animal Production, 351:2-30.

Fanimo, A. O., Oduguwa, O. O., Jimoh, Y. O. and Farronbi, A. O. 2007. Performance and carcass evaluation of broiler chick fed shrimp waste meal supplemented with synthetic amino acids. Nigerian Journal of Animal Production. 25(1):17-21.

Google Earth 2017. Geo Names, Geographical database, Travelling Guide for Calabar, Cross River State. Nigeria Time Zone.

Hedge, S. N., Rolls, B. A., Turrey, C. and Coate, M. E.1978. The effects on chicks of dietary fibre from 
different sources: a growth factor in wheat bran. British Journal of Nutrition. 40:63-69.

Knogdah, I. A.1985. Dietary fibre are trouble makers. Poultry International. Watt Publication.

Monsi, A. 1999. Appraisal of interrelationship among live measurements at different ages in meat-type chickens. Nigerian Journal of Animal Production. 19(1 and 2):15-24.

Nsa, E. E., Anya, M. I. and Okon, B 2009. Comparative evaluation of five animal protein concentrates in broiler finisher diets. Proceedings of the $43^{\text {rd }}$ Annual Conference of the Agricultural Society of Nigeria, Abuja.pp893-895.

Ojabo, L. D., Oluremi, O. I. and Uza, D. V. 2014. Effects of feeding sundried sweet orange (Citrus sinensis) fruit peel on pullet chick performance. Research Opinion of Animal Vertinary Science. 4(9):484-488.

Ojewola, G. S. 2005. Comparative utilization of three animal protein sources by broiler chickens. International Journal of Poultry Science. 4(7):462-467.

Ogungbeuro, S. D., Raji, M. O., Bamgbose, A. M., Oso, A. O., Sogunle, O. M. 2013. Effects of replacement of cashewnut mealmaize offal with maize on the performance of turkey poults. Int. Journal of Agric. Biossci. 2(4):164167.

Olomu, J. M. 2012. Monogastric animal nutrition. Principles and Practice. A Jachem Press.

Oyawoye, E. O. and Nelson, F. S. 2002. Optimum level of inclusion of rice offal in the diet of young cockrels. Proceedings of the $20^{\text {th }}$ Annual
National Conference of the Nigerian Society for Animal Production. Minna, Niger State Nigeria.

Oyedepo, L. O. S. Ameer, S. A. Adedeji, T. A., Ogundije, R. I. and Ige, A. O. 2012. Prediction of body weight and other linear body measurement of commercial layer strain chickens. Asian Journal of Animal Sciences, 6: 33-122.

Oyewola, G. S. 2005. Comperative utilization of three animal protein sources by broiler chickens. International Journal of Poultry Science. 4(7):462-467.

Peter, S. O., Adeleke, M. A., Oje, O. A. Adebambo, O. A. and Ikeobi, C. O. N. 2006. Bio-prediction of live weight from linear body measurement traits among pure and cross bred chicken Nigeria poultry science Journal 4:1-6.

Reddy, D. V. 2007. Applied Nutrition: livestock, poultry, human, pet and laboratory animal nutrition. Vijay Publishers. Pp. 58-62.

SAS 2012. SAS users guide: statistics released version 8-3. Statistical analysis system institute Inc. North California.

Ukoha, O. A., Nsa, E. E., Onunkwo, D. N. and Ezike, J. 2019. Comparative evaluation of fish, cray fish waste, meat and blood meal for broiler production. Nig. J. Anim. Prod. 46(1) 71-76.

Received: $12^{\text {th }}$ February, 2019

Accepted: $25^{\text {th }}$ July, 2019 